\title{
ANALYSIS OF THE INFLUENCE OF THE PROTESTANT RELIGION ON THE ECONOMIC GROWTH OF GERMAN REICH (1879-1910)
}

\author{
ANALIZA WPŁYWU RELIGII PROTESTANCKIEJ NA WZROST \\ GOSPODARCZY RZESZY NIEMIECKIEJ (1879-1910)
}

\author{
Department of Economics, West Pomeranian University of Technology, Szczecin \\ Żołnierska 47, 71-210 Szczecin, Poland, ORCID: 0000-0001-9578-5741 \\ e-mail: janusz.myszczyszyn@zut.edu.pl
}

\begin{abstract}
Summary. Despite many previous studies, the author has applied econometric analysis to verify the validity of the Weber's thesis on the positive impact of the Protestant religion on economic growth presented in "The Protestant Ethics and the Spirit of Capitalism". To this end, gross GDP of German Reich in 1879-1910 was analyzed. According to the results of multiple regression analysis (least-square method), the Protestant religion, in addition to the level of emigration and the percentage of people working in agriculture, played a significant part in the creation of social welfare (the gross domestic product GDP) in Germany. However, it is a negative dependence as the increase in the number of Protestants by $1 \%$ led to a decline in GDP growth of Germany by $6.146 \%$ and thus the hypothesis was not supported. The determination coefficient was $33.13 \%$, which only proves that there were other factors that influenced the social welfare of Germany which were not included in the model. A surprising finding was the lack of relevance of the variable of the percentage of pupils and students.
\end{abstract}

Key words: economic growth and Protestant religion, the German Reich, Max Weber, cliometrics.

Słowa kluczowe: wzrost gospodarczy a religia protestancka, Rzesza Niemiecka, Max Weber, kliometria.

\section{INTRODUCTION}

The relationship between religion and the development of capitalist economy has been a subject of scientists' interest for long.

On the one hand, there have been efforts to study the influence of religion on economic growth and its dynamics from the macroeconomic perspective, as well as the impact of religion on its followers in terms of personal traits and attitudes that play a role in the forming of Homo economicus (Höhener and Schaltegger 2012). On the other hand, the religious variable is treated as a variable dependent on the level of the economic development (the level of secularisation).

Max Weber (1864-1920) wide-ranging contributions gave critical impetus to the birth of modern sociology and the study of influence of religion on the development of the capitalist order.

One of Weber's theses assumed that religious beliefs influence the way people feel, think and behave, thus affecting their personality traits, individual mentality, which in turn has a huge bearing on economy. 
Weber described the development of capitalism as a gradual process of rationalization by which modern society has become greatly concerned with efficiency, dehumanization, calculability and predictability. Rationalization, guided by reason and practicality, transformed modern society and played an important role in the development of capitalism. The process of increasing rationalization is especially vivid in case of the Protestant theologies that have moved towards rational means of economic gain as a way of dealing with existential and religious anxieties. The author of this analysis aimed to investigate whether, according to Max Weber's thesis, the Protestant religion influenced the pace of the economic growth of Germany.

The author applied his own econometric model that included the GDP and the religioun variable to examine the correlation of religion and economic growth of the German Reich in 1879-1910 (Myszczyszyn 2013, 2016). The following research hypothesis was formulated: Protestant religion was an important factor influencing the economic growth of the German Reich.

Despite the importance of the religioun variable, it may be regarded as one of many factors in the rapid economic growth of Germany.

\section{MAX WEBER'S VIEWS EXPRESSED IN „THE PROTESTANT ETHICS”}

The influence of religion was understood by German economists in various ways, to mention just the views of Max Weber and Werner Sombart. Weber believed that the reformed religions played a major role in the rationalization and development of the spirit of capitalism, whereas Sombart emphasized the importance of the Jewish religion in economic life.

In his work Die protestantische Ethik und der Geist des Kapitalismus $(1905,1930)$, Weber proved that economic calculations used by merchants and tradesmen had a major impact in the formation of the "calculating spirit" and rational economic behaviour, thus on the rationality of management and policies (e.g. commercial), and spread to other spheres of economic life. Capitalism was the highest form of that rationality. Weber called capitalism „the most fateful in our modern life" (Weber 2010, p. 8). He observed that even the most irresistible desire for possession was not at all tantamount to capitalism, and even more so to its spirit. He claimed that capitalism was identical with „(...) the pursuit of profit, and forever renewed profit, by means of continuous, rational, capitalistic enterprise. (...) This enterprise must be continuous, because in a capitalistic society, anyone who did not take advantage of opportunities for profit-making would be doomed to extinction" (p. 8). Weber defined profit as "(...) a capitalistic economic action that rests on the expectation of profit by the utilization of opportunities for exchange, on (formally) peaceful chances for profit" (Weber 2010, p. 8).

Weber pointed out that religious beliefs were not irrelevant to the economy, and cultivating such features as the ethics of work, honesty (and trust), saving, charity, the pursuit of goals by individuals with the assumption of certain risks could have a positive impact on the economy. He assumed that religion could influence the economy by the power of rationality. Hence, the fundamental question was about the relationship between different religions and economy. 
Weber presented in his book eyewitness examples of religious behavior typical of particular Christian denominations. He pointed out how important it was to define what "work” actually means for particular Christian denominations. For example for Martin Luther (1483-1546), it was understood as divine service, and for Calvinism an economic success was a sign of vocation (predestination). In the Calvinist Protestantism, it was almost impossible to "deserve" salvation as individuals were either predestined for salvation or not (McCleary and Barro 2009). „The rationalization of the world, the elimination of magic as a means to salvation, the Catholics had not carried nearly so far as the Puritans (and before them the Jews) had done. To the Catholic the absolution of his Church was a compensation for his own imperfection. The priest was a magician who performed the miracle of transubstantiation, and who held the key to eternal life in his hand. One could turn to him in grief and penitence. (...) the Calvinist was doomed by an inexorable fate, admitting of no mitigation. For him such friendly and human comforts did not exist. He could not hope to atone for hours of weakness or of thoughtlessness by increased good will at other times, as the Catholic or even the Lutheran could. The God of Calvinism demanded of his believers not single good works, but a life of good works combined into a unified system. There was no place for the very human Catholic cycle of sin, repentance, atonement, release, followed by renewed sin. Nor was there any balance of merit for a life as a whole which could be adjusted by temporal punishments or the Churches' means of grace..." (Weber 2005, p. 71). At the same time, Weber expressed how the reformed churches had influenced human behavior and temporal affairs, unlike the Catholic religion. "The Catholic is quieter, having less of the acquisitive impulse; he prefers a life of the greatest possible security, even with a smaller income, to a life of risk and excitement, even though it may bring the chance of gaining honour and riches. The proverb says jokingly, 'either eat well or sleep well'. In the present case the Protestant prefers to eat well, the Catholic to sleep undisturbed" (Weber 2005, p. 8).

Weber's arguments led to believe that followers of the Protestant religion, and especially the followers of Calvinism, had essentially influenced the economic development of Western countries. Weber gave an example of their positive impact on the economies of the United States, England and the Netherlands. "Among journeymen, in other words, the "Catholics show a stronger propensity to remain in their crafts, that is they more often become master craftsmen, whereas the Protestants are attracted to a larger extent into the factories in order to fill the upper ranks of skilled labour and administrative positions" (Weber 2005, p. 6).

Another representative of the younger German historical school, Werner Sombart, believed that the Protestant religion was not at all a motive force (spirit) for capitalism. He claimed that the Protestant religions (including Calvinism) in the early stages of their origins were hostile to capitalism itself, so it is hard to believe that they could have propelled the development of the spirit of capitalism. In addition he pointed out that the development of capitalism (including British capitalism) was probably influenced by factors completely different than Calvinism and its English-Scottish variant, i.e. Puritanism (Sombart 1920).

In Der Bourgeois, Sombart argued that all religions equally supported the cultivation of the bourgeois virtues: diligence, thriftiness and honesty, and also the rationalization and the methodology of life (Sombart 1920). He also made a controversial thesis that „Amerika in allen seinen Teilen ist Judenland" (p. 31). He recalled the contribution of Jews towards the development of capitalism and their merit in terms of inclusion of the American continent in the European economic system (Sombart 1911). 
After reading Sombart's work, Max Weber inquired „What are the specific achievements of the Jews in the Middle Ages and the modern times? Loans from pawnshops to the financing of big states, some types of trade, among which the small stallholder's and wandering trades and village-specific "trade in products”, certain areas of wholesale trade" (p. 468) were definitely on the forefront. He added that in the Jewish activity there were no significant features of modern capitalism "the organisation of work in the form of cottage industry, manufactory and factory" (Weber 2002, p. 468).

\section{RELIGION AS A SPECIFIC COMMODITY - REVIEW OF THE RESEARCH FINDINGS}

Since the times of Adam Smith, believers have been perceived as members of an economic club. Belonging to a religious community influences both the individual behavior of its members (through strict rules, participation in rites, punishments for violation of rules, perceiving others), and also affects the whole social group as an important element of the social capital.

In economic modeling, religion was treated as a specific commodity. A single person became a follower of a particular religion that involved him/ her in specific religious practices. From the economic point of view, both costs and benefits of religious affiliation were to be considered in terms of multiplication of social welfare (lannaccone et al. 1997).

In the understanding of the new institutional economy, religion is something that creates structure and is characterized by informal rules. Thus religion, besides such factors as manners, customs, tradition, is an important social factor, deeply ingrained in every community and influencing its development (Hoffmann 2011).

In general, religion may affect economy in two ways:

- by having (indirect) influence on a person's individual characteristics and mindset. Aggregation of these features at the level of society may affect economy, including economic growth;

- by having direct influence on social behavior and the fact that belonging to a certain religious denomination strengthens economic cooperation between members of the community (Höhener and Schaltegger 2012).

Studies on the influence of religion on individual behavior and studies aimed at verification of Weber's thesis have led to various conclusions, among them:

- there is a negative correlation between personal income and religious affiliation (Lipford and Tollison 2003);

- there is a higher correlation between religious affiliation and personal income for Catholics and Jews than Protestants (Steen 2004);

- there is a positive correlation between the percentage of Protestants and the number of suicides; Protestantism has positive influence on the economic potential, which decreases with the increase of education (Prussia). Protestant theology per se did not really have an impact on the Protestant ethics, but rather it was the education that positively influenced the work ethos and the virtue of frugality (Becker and Woessmann 2009, 2011);

- there is a strong positive correlation between religious affiliation and tax morale (inclination to pay taxes). The variable correlation coefficient is always high for particular denominations (Torgler 2006); 
- there is positive influence of religiosity on attitude towards thriftiness, cooperation, women's rights, etc., and thus positive impact on the economic growth (Guiso et al. 2003);

- the Catholic religion positively affects life satisfaction, health, family relations, leads to lower unemployment rates and stronger social bonding in comparison to non-believers (Tao 2008).

Vast scientific research has been conducted to determine the correlation between economic growth and religious change (i.e., the indirect influence of religion), among others by: L. Guiso, P. Sapienza and L. Zingales. It has been established that:

- religiously active citizens are generally less tolerant and have conservative views, e.g. on the role of women in society;

- religiously inclined citizens emphasize that people are by nature lazy and do not have sufficient willpower. In particular, the vanity of man is exposed in Protestantism;

- Christian religions have a positive impact on the economic growth, whereas Islam has a negative influence;

- compared to Catholics, Protestants have more confidence in others and also in institutions. They are less tolerant of tax fraud and are more likely to pay taxes;

- Catholics, more than Protestants, support private ownership; property plays a major role in Hinduism and the smallest in Islam;

- Jews adhere most to tax law and are least tolerant of tax evasion, followed by Protestants and Hindus; Catholics come last in this ranking;

- the least likely to give bribes and other property gains are the Buddhists, then Protestants and followers of Islam, Catholics close the list;

- Catholics are more positive than Protestants about the rules of economic competition.

The authors have concluded that religion has a positive effect on economic growth, but at the same time underline that there is a variety of other factors that affect economic growth, as well as religion itself. It is not easy to point out which religion is the most conducive to the growth of economic prosperity. Definitely, Christian religions are more supportive of economic growth than Islam. At the same time, the authors do not point exactly to a Christian denomination that most favours economic growth (Guisoa et al. 2003).

In 2001, Weber's thesis was investigated by J. Delacroix and F. Nielsen. They considered statistical data referring to Western European countries from the end of the 18th century. The authors investigated how the religious variable (the percentage of Protestant population) correlated with Protestant attitudes (e.g. frugality, establishment of exchanges, development of communication networks, social division of labour (reduction of employment in agriculture at the expense of industry and services)) and the development of capitalism. Contrary to the thesis proclaimed by Weber, the researchers did not confirm that a significant correlation existed between Protestantism and the level of social per capita income, stock market assumptions and social division of labour. Surprisingly, a negative correlation coefficient between Protestantism and the pace of railway network expansion was obtained. The only significant correlation coefficient was observed between Protestantism and the increase in bank deposits, which could be interpreted as a sign of greater inclination towards thriftiness on the part of the followers of the Reformed religions (Delacroix and Nielsen 2001). 
Shawn F. Dorius and Wayne Baker have concluded that the Weberian hypothesis needs to be reconsidered and changes in people's mentality in reference to secular values should be taken into account rather than only the religion factor (Dorius and Baker 2012; McCleary and Barro 2012).

R.M. McCleary, R.J. Barro studied the influence of religious variables on economic growth (the real GDP per capita (the gross domestic product)) in three periods: 1965-1975, 1975-1985, 1985-1995. The results demonstrated that in the case of the Protestant religion (and Islam) the correlation was negative (McCleary and Barro 2009).

\section{STATISTICAL ANALYSIS - GDP LEVEL MODEL}

At the beginning of the 20th century, there were 90 million Protestants and 173 million Catholics in Europe (Informationen zur politischen Bildung 2012).

In German Reich (formed in 1871), out of 41058792 inhabitants, nearly 25.6 million people declared their affiliation to the Protestant denominations, about 14.9 million were Catholics, there were over 82 thousand of followers of other Christian sects and more than 512 thousand followers of Judaism.

The Kingdom of Prussia was the largest national state in the German Empire. The religious demographics of Prussia in 1871 was as follows:

- $64.97 \%$ were followers of the Protestant religion;

- 33.49\% declared Catholic affiliation;

- $0.22 \%$ of the population were other Christians;

- $1.32 \%$ professed Judaism (Statistisches Jahrbuch für das Deutsche Reich 1914).

It is worth noting the considerable regional variation in the number of Catholics and Protestants, especially in the provinces (eastern) where a large proportion of the population was Polish.

Pursuant to Statistisches Jahrbuch für den Preussischen Staat (1903), in the provinces of Pommern, Westpommern, Branderburg, Protestantism dominated, while Catholics predominated in the province of Posen Province and Schlesien. In the Province of Westpommern, the followers of the two rites were similar in number (Statistisches Jahrbuch für den Preussischen Staat 1904).

An analysis of the percentage of particular denominations between 1871 and 1910, both for the German Reich and the Kingdom of Prussia, shows that the proportions changed slightly in favour of Catholics. In the entire Reich in 1910, Protestants constituted $61.5 \%$ of total believers $(1.1 \%$ decrease compared to 1871$)$, Catholics $36.6 \%(0.72 \%$ increase compared to 1871$)$, Jews $0.95 \%$ (0.29\% decrease compared to 1871$)$ and other Christians $0.44 \%$ (increase by $0.23 \%$ compared to 1871 ) - Fig. 1 .

To determine the relationship between GDP growth and independent variables describing the economy of Germany, the author has used a model he developed previously to assess the influence of the railway variable on economic growth of Germany. Among the collected statistical data describing the state of German economy, the author used:

- the percentage of persons employed in agriculture in relation to employees employed in the whole national economy (\%) (hereinafter referred to as AW). 
To determine the relationship between GDP growth and independent variables describing the economy of Germany, the author has used the model he developed previously to assess the influence of the railway variable for the economic growth of Germany. The collected statistical data describing the state of the German economy included:

- the percentage of persons employed in agriculture in relation to employees employed in the whole national economy (\%) (hereinafter referred to as AW);

- emigration (in thousands) (hereinafter referred to as EMt-1);

- investment in economy (RM in million) (hereinafter referred to as I);

- number of marriages (in thousands) (hereinafter referred to as MA);

- number of pupils and students (in thousands) (hereinafter referred to as STt-1);

- number of Protestants (in thousands) (hereinafter referred to as PR) (Statistisches Jahrbuch für das Deutsche Reich 1880-1913; Statistisches Jahrbuch für den Preussischen Staat 1904; Hoffman 1965; Maddison 2015).

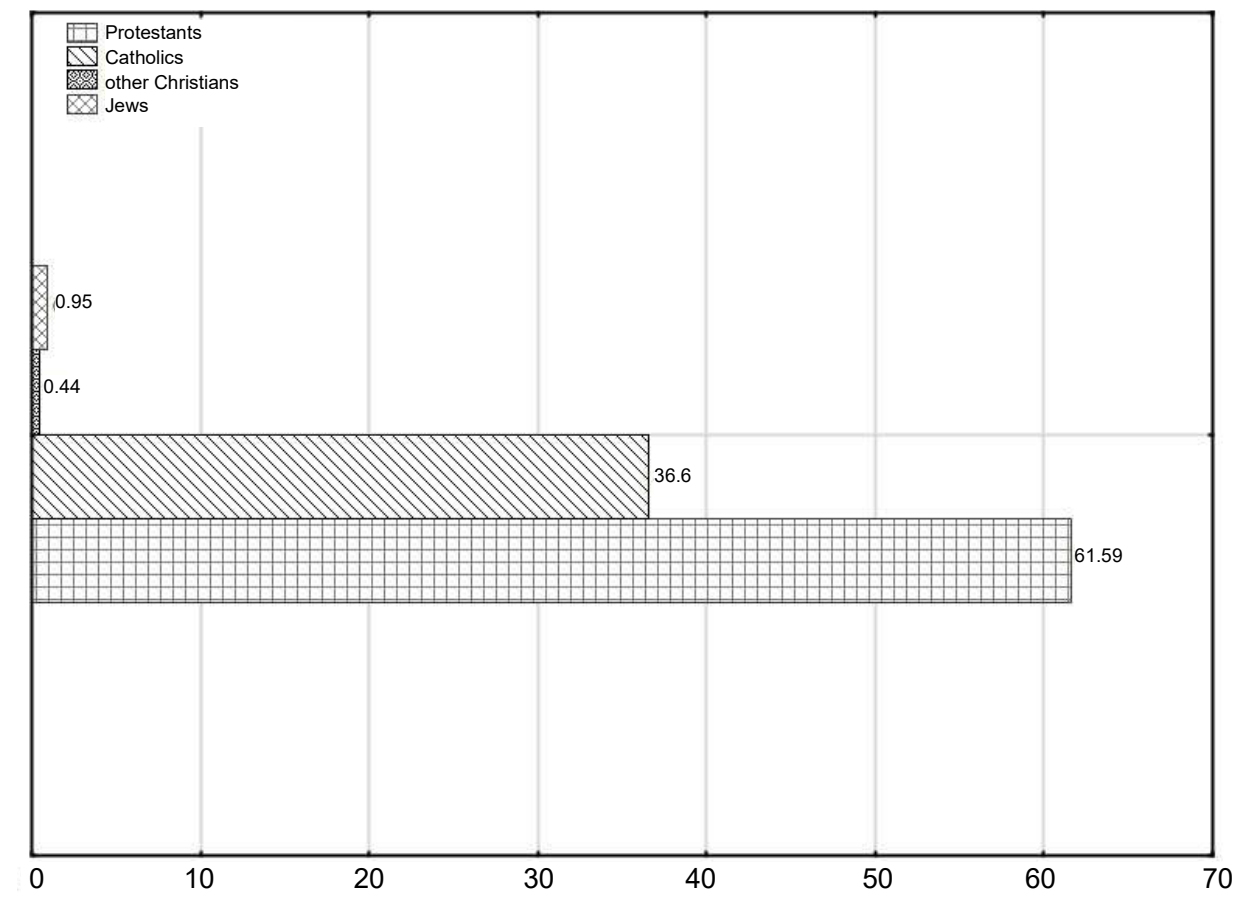

Fig. 1. Followers of the major religions in the German Reich in 1910 [\%] Source: own calculation based on: Statistisches Jahrbuch für das Deutsche Reich... (1917).

The research period was conditioned by the availability of statistical data published in the Statistisches Jahrbuch für das Deutsche Reich concerning individual religions, and covers the time series 1879-1910'.

In the proposed model, the GDP level was an endogenous variable and the other variables used were the explanatory variables.

The function took the general form:

\footnotetext{
${ }^{1}$ Assumptions and results for the GDP level model and GDP dynamics are included, among others in the author's work: Mata (2008); Myszczyszyn (2013, 2016).
} 


$$
\ln \mathrm{Y}_{\mathrm{t}}=\beta_{0}+\sum_{t=1}^{n} \beta_{i} \ln x_{i, t}+\varepsilon_{t}
$$

where:

$Y_{t}-$ GDP of Germany (1879-1910),

$X_{i, t}$ - selected explanatory variables characterizing German economy,

Bi- structural parameters,

Bo- constant term,

In - natural logarithm,

$\varepsilon$ - random component.

In this context, the structural parameter $\beta i$ determines the elasticity of the variable dependent on the explanatory variables.

They describe a relative change in GDP (in USD 1990) due to the relative change of only one of the factors highlighted by $1 \%$, with a fixed level of other factors (ceteris paribus). At the same time it has been assumed that the critical correlation value was $0.344^{2}$. All the exogenous variables proved to be significantly correlated with the explanatory variable.

The author assessed the stationarity of the variables using two tests: the Dickey Fuller (ADF) extended test) and the Kwiatkowski-Philips-Schmidt-Shina test (KPSS) - Kębłowski (2003).

Results of the integration analysis showed stationarity of variables integrated of order 0 for: the level of investment, the level of emigration and the first increases for: GDP, employment in agriculture, number of marriages, the number of pupils and students, the number of protestants.

\section{RESULTS AND THEIR ANALYSIS}

In order to estimate the structural parameters of the above model, the least-square method (LSM) was applied. The GDP level model taking into account the religious variable the number of Protestants (the PR variable):

$$
\begin{aligned}
& \ln Y_{t}=0,171-6,146 / n P R-0,021 / n E_{\mathrm{t}-1}-0,89 / n A W
\end{aligned}
$$

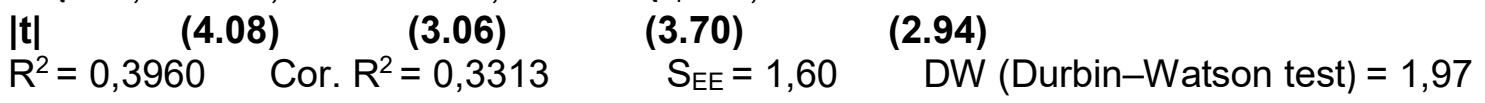

where:

$Y_{t}-$ GDP growth levels in Germany between 1879 and 1910,

$P R$ - increase in the number of Protestants,

$E M_{t-1}$ - level of emigration ( $t-1$ ) (in thousands),

$\mathrm{AW}$ - increase in the number of people employed in agriculture.

For the above modeling phase, the determination coefficient $\mathrm{R}^{2}$ was $39.6 \%$ and its adjusted value was $33.13 \%$.

The significance test was based on the distribution of t-Student statistics.

The inequality $|\mathrm{t}|>t_{a}(|\mathrm{t}|>2.0484)$ was fulfilled for three parameters. The variables for the level of investment $(|t|=0.768$, increase in the number of marriages $(|t|=0.414)$, and increase in the number of pupils and students $(|t|=0.438)$ turned out to be insignificant.

$$
2 r^{*}=\sqrt{\frac{t_{\alpha, N-2}^{2}}{N-2+t_{\alpha, N-2}^{2}}} \approx 0,344
$$


To test the homoscedasticity, the Breusch-Pagan test was performed. The value of LM 2.98 , based on an empirical level of significance (the values $p>0.05$ ) equal to 0.39 , had no basis for rejecting the $\mathrm{H}_{0}$ hypothesis of the homoscedasticity of the model residues.

The evaluation of the structural parameters for the above equation (assuming ceteris paribus) led to the following conclusions:

a) increase in the number of Protestants by $1 \%$ led to a decrease in the German GDP by $6.146 \%$,

b) decrease in emigration by $1 \%$ led to an increase in GDP growth of $0.02 \%$,

c) decline in the percentage of population employed in agriculture by $1 \%$ resulted in an increase in GDP growth of $0.89 \%$,

It should be added, however, that in principle, both the percentage of employed in agriculture and the level of emigration in the analyzed period (1879-1910) showed a declining trend, i.e., they affected the increase in GDP. On the other hand, the number of Protestants increased (mainly due to significant natural increase).

The results indicate that religious variable turned was the significant variable affecting the GDP of Germany and thus support the hypothesis. It should be noted that factors significantly influencing the GDP endogenous variable in 1879-1910 were:

- demographic factors, including the level of emigration analyzed by the author;

- development of human capital as a proportion of the number of pupils and students (STt-1) was irrelevant, although this comes as a surprise. Similar irrelevance was observed for the variable: number of marriages concluded (in thousands);

- decline in employment in agriculture proved to be significant, as was the case in the earlier period (1850-1913). In Germany employment in agriculture still remained significant in proportion to total employment in national economy. For example, in 1913 it was still almost $35 \%$ of the total number of employees.

- number of the Protestants (PR), despite the fact that the variable turned out to be significant, the (absolute) increase in the number of Protestant population contributed to a decline in GDP growth, which stands in stark contrast to the thesis made by Max Weber. It should be noted, however, that in the years 1871-1910 the percentage of Protestants in the Reich decreased by $1.1 \%$.

\section{CONCLUSIONS}

For more than 100 years, Weber's hypothesis on the economic role of Protestant work ethics and the impact of religious beliefs on the development of the spirit of capitalism has been the subject of many theoretical and empirical studies. The thesis still remains controversial. On the one hand, belonging to a particular religion had economic consequences for Prussia in the nineteenth century. On the other, it was not only the Protestant ethics that affected human motivation and was the driving force of economic development, but also the typically Protestant focus on continuous education and selfimprovement (Wagener 2010).

Results of the research are ambiguous, but in many cases "the religious variable" proved to be the significant independent variable. 
The author attempted to verify Max Weber's thesis on the positive impact of the Protestant religion on the economic growth of the German Reich at the early stage capitalism order. The results show that the religious affiliation was, in addition to other variables, a significant variable in the GDP model of Germany between 1879 and 1910. However, it is surprising that Protestantism had a negative impact on the growth of GDP as it declined as the (absolute) number of Protestants increased (though the percentage of Protestants declined slightly). It may be added that the $\mathrm{R}^{2}$ determination coefficient (adjusted) is $33.13 \%$, which is proof that there were other factors, not included in the model, which also affected the economic growth of the Reich.

\section{REFERENCES}

Becker S., Woessmann L. 2011. Knocking on heaven's door? Protestantism and suicide. CESifo Work. Pap. 3499, 1-30.

Becker S., Woessmann L. 2009. Was Weber wrong? A human capital theory of protestant economic history. Quarterly J. Econ. 124(2), 531-596.

Becker S., Woessmann L. 2010. The effect of protestantism on education before the industrialization: Evidence from 1816 Prussia. Econ. Lett. 107, 224-228.

Brodbeck K. 2006. Religion und Wirtschaft Asien im Vergleich zum westlichen Kulturraum. Praxis-Perspektiven 8, 17-27.

Dambeck H. 2007. Religion und Arbeit. Protestantische Länder haben Erwerbsquote, Spiegel von Sonntag, 7 Oktober 2007.

Delacroix J., Nielsen F. 2001. The beloved myth: Protestantism and the rise of industrial capitalism in nineteenth-century Europe. Soc. Forces 802, 509-553.

Dorius S., Baker W. 2012. The Spirit of Capitalism, Economic Development, and National Wealth, Population Studies Center Res. Rep. 12, 771.

Fremdling R. 1985. Eisenbahnen und deutsches Wirtschaftswachstum 1840-1879. Ein Beitrag zur Entwicklungstheorie und zur Theorie der Infrastruktur. Dortmund, Verlag: Gesellschaft für Westfälische Wirtschaftsgeschichte.

Guiso L., Sapienza P., Zingales L. 2003. People's opium? Religion and economic attitudes. J. Monet. Econ. 50, 225-282.

Hoffman W.G. 1965. Das Wachstum der deutschen Wirtschaft seit der Mitte des 19. Jahrhunderts. Berlin, Springer Verlag, 352-354, 368-370.

Hoffmann R. 2011. The experimental economics of religion. CeDEx Disc. Pap. Ser. 7, 1-30.

Höhener J., Schaltegger Ch. 2012. Religionsökonomie: eine Übersicht, Crema Center for Research in Economics, Management and Arts. Working Pap. 8, 1-16.

lannaccone L.R., Finke R., Stark R. 1997. Deregulating religion: The economics of church and state. Econ. Inquiry $35,350-364$.

Informationen zur politischen Bildung 315, nr. 315/2012. Das 19. Jahrhundert, www.bpb.de/ /izpb/142102/das-19-jahrhundert, access: 10.12.2017.

Kaesler D. 2014. Gehäuse der Hörigkeit. Der Spiegel 17, 119-121.

Kaesler D. 2014. Max Weber: Preuße, Denker, Muttersohn. Eine Biograpfie. München, CH Beck.

Kaliński J. 2008. Historia gospodarcza XIX i XX w. Warszawa, PWE. [in Polish]

Kębłowski P. 2003. Test hipotezy wspólnego potwierdzenia stopnia integracji ADF-KPSS [ADF-KPSS Test for Join Confirmation Hypothesis of Unit Root]. Prz. Statyst. 3, 87-104. [in Polish]

Kruhöfer G. 2002. Grundlinien des Glaubens. Ein biblisch-theologischer Leitfaden. Göttingen, Vandenhoeck\&Ruprecht.

Lipford J., Tollison R. 2003. Religious participation and income. J. Econ. Behav. Org. 51, 249-260. 
Maddison A. Historical statistics for the world economy: 1-2003 AD, www.sais-jhu.edu/library/ /subjectguides/stats.htm, access: 2.12.2015.

Mata M., Love J. 2008. A reversal in the historical role of tariffs in economic growth? The cases of Brazil and Portugal. Est. Econ., São Paulo 38(3), 461-492.

McCleary R.M., Barro R.J. 2009. Religia i gospodarka [Religion and economy]. Gosp. Nar. 1-2, 124. [in Polish]

Myszczyszyn J. 2013. Wpływ kolei żelaznych na wzrost gospodarczy Niemiec 1840-1913. Łódź, Wydaw. UŁódz. [in Polish]

Myszczyszyn J. 2016. Use of econometric modelling to evaluate the impact of the railways on economic growth of German Reich (1879-1913). Actual Probl. Econ. 181(7), 475-484.

Skodlarski J., Matera R. 2004. Gospodarka światowa. Geneza i rozwój. Warszawa, PWN. [in Polish]

Sombart W. 1920. Der Bourgeois. Műnchen-Leipzig, Verlag von Wunder \& Humblot, 324.

Sombart W. 1911. Die Juden und das Wirtschaftsleben. Leipzig, Verlag Druncker\&Humblot, 31-32.

Statistisches Jahrbuch für den Preussischen Staat. 1903. Berlin, Königlichen Statistischen Bureau.

Statlisches Jahrbuch für das Deutsche Reich, Kaiserlichen Statistischen Amt, 1880-1913. 1917. Berlin, Puttkamer und Mühlbrecht.

Steen T.P. 2004. The relationship between religion and earnings: recent evidence from the NLS Youth Cohort. Inter. J. Soc. Econ. 31(5), 572-581.

Steiner L., Lienert L., Frey B. 2010. Economics, religion and happiness, Zeitschrift für Wirtschaftsund Unternehmensethik 11, http://nbn-resolving.de/urn:nbn:de:0168-ssoar, access: 10.05.2016.

Tao H. 2008. What makes devout Christians happier? Evidence from Taiwan. Appl. Econ. 40, 905-919.

Torgler B. 2006. The importance of faith: Tax morale and religiosity. J. Econ. Beh. Org. 61, 81-109.

Wagener H. 2010. Die 101 wichtigsten Fragen - Konjunktur und Wirtschaftswachstum. München, CH Beck, 100.

Weber M. 2010. Etyka protestancka a duch kapitalizmu. Warszawa, Wydaw. Aletheia, 8-9. [in Polish]

Weber M. 2002. Gospodarka i społeczeństwo. Zarys socjologii rozumiejącej. Warszawa, PWN, 466-487. [in Polish]

Weber M. 2005. The protestant ethic and the spirit of capitalism. London, RoutledgeTaylor \&Franch Group, 71.

Williamson O.E. 1998. Transaction cost economics: How it works; where it is headed. The Economist 146(1), 23-58

Streszczenie. Autor wykorzystał analizę ekonometryczną w celu weryfikacji tezy Maxa Webera przedstawionej w dziele „Etyka protestancka a duch kapitalizmu” o rzekomo pozytywnym oddziaływaniu religii protestanckiej na wzrost gospodarczy. W tym celu przeanalizowano poziom produktu krajowego brutto Rzeszy Niemieckiej w latach 1879-1910. Zgodnie z otrzymanymi wynikami regresji wielorakiej (klasyczna metoda najmniejszych kwadratów) religia protestancka, oprócz poziomu emigracji, odsetka pracujących w rolnictwie, była istotna dla tworzenia społecznego dobrobytu (PKB) Niemiec. Jest to jednak zależność ujemna, gdyż wzrost liczby protestantów o $1 \%$ prowadził do spadku przyrostu poziomu PKB Niemiec ○ 6,146\%. Tym samym nie potwierdzono słuszności ww. tezy. Współczynnik determinacji wyniósł $33,13 \%$, co dowodzi jedynie tego, że na dobrobyt społeczny Niemiec miały wpływ także inne czynniki, których w modelu nie uwzględniono. Dużym zaskoczeniem był brak istotności zmiennej odsetek liczby uczniów i studentów. 
